Article

\title{
Impact of Aerosol-Cloud Cycling on Aqueous Secondary Organic Aerosol Formation
}

\author{
William G. Tsui ${ }^{1}$, Joseph L. Woo ${ }^{2}\left(\mathbb{D}\right.$ and V. Faye McNeill ${ }^{1, *(1)}$ \\ 1 Department of Chemical Engineering, Columbia University, New York, NY 10027, USA; \\ wgt2105@columbia.edu \\ 2 Department of Chemical and Biomolecular Engineering, Lafayette College, Easton, PA 18042, USA; \\ wooj@lafayette.edu \\ * Correspondence: vfm2103@columbia.edu; Tel.: +1-212-854-2869
}

Received: 26 September 2019; Accepted: 28 October 2019; Published: 31 October 2019

\begin{abstract}
Chemical processing of organic material in aqueous atmospheric aerosols and cloudwater is known to form secondary organic aerosols (SOA), although the extent to which each of these processes contributes to total aerosol mass is unclear. In this study, we use GAMMA 5.0, a photochemical box model with coupled gas and aqueous-phase chemistry, to consider the impact of aqueous organic reactions in both aqueous aerosols and clouds on isoprene epoxydiol (IEPOX) SOA over a range of $\mathrm{pH}$ for both aqueous phases, including cycling between cloud and aerosol within a single simulation. Low $\mathrm{pH}$ aqueous aerosol, in the absence of organic coatings or other morphology which may limit uptake of IEPOX, is found to be an efficient source of IEPOX SOA, consistent with previous work. Cloudwater at $\mathrm{pH} 4$ or lower is also found to be a potentially significant source of IEPOX SOA. This phenomenon is primarily attributed to the relatively high uptake of IEPOX to clouds as a result of higher water content in clouds as compared with aerosol. For more acidic cloudwater, the aqueous organic material is comprised primarily of IEPOX SOA and lower-volatility organic acids. Both cloudwater $\mathrm{pH}$ and the time of day or sequence of aerosol-to-cloud or cloud-to-aerosol transitions impacted final aqueous SOA mass and composition in the simulations. The potential significance of cloud processing as a contributor to IEPOX SOA production could account for discrepancies between predicted IEPOX SOA mass from atmospheric models and measured ambient IEPOX SOA mass, or observations of IEPOX $\mathrm{SOA}$ in locations where mass transfer limitations are expected in aerosol particles.
\end{abstract}

Keywords: secondary organic aerosol; isoprene epoxydiol; aqueous aerosol; cloudwater

\section{Introduction}

Aerosols are known to affect human health, air quality, and climate and are ubiquitous in the atmosphere. They can also act as condensation nuclei to form cloud droplets, and evaporation of liquid water from the cloud droplets allows for cycling between cloud droplets and aqueous aerosols [1-4]. Cycling between these two aqueous regimes can occur on timescales of seconds to minutes, significantly shorter than the typical lifetime of aerosols, which is roughly one week [5,6]. The uptake of water by aerosols or the evaporation of cloud droplets has the potential to impact atmospheric chemistry by altering the partitioning of semivolatile species, or perturbing equilibrium reactions in the aqueous phase. Although the composition of aqueous aerosols can vary considerably, liquid water and aqueous organic material are a significant portion of atmospheric aerosol mass [7-9], and much of the aqueous-phase organic material that comprises aerosols is known to be secondary. The cycling between aqueous aerosols and cloudwater provides two different aqueous environments in which aqueous secondary organic aerosol material (aqSOA) can form [10,11]. Since both environments are aqueous, the same chemical processes occur in both environments. However, different processes are dominant due to the difference 
in water content, and therefore dilution of nonvolatile components, with aqueous aerosols having less water content per volume of air than cloudwater where clouds are present [12]. For example, relatively lower water content and generally lower $\mathrm{pH}$ are typical of aqueous aerosols, and high concentrations of organic material can limit the availability of oxidants. This results in dark (nonphotochemical) reactions, such as acid-catalyzed accretion reactions and organosulfate formation, being more dominant in aerosol water than in cloudwater [8]. Typical cloudwater $\mathrm{pH}$ can range between three and six, as measured at the Whiteface Mountain Field Station summit observatory in Wilmington, NY, USA [13,14], whereas aerosol particles tend to be considerably more acidic [15].

Isoprene is the most abundant nonmethane hydrocarbon gas in the atmosphere and a major source of aqSOA [16-18]. One of the most significant pathways of aqSOA formation from isoprene is through the gas-phase photooxidation of isoprene to form isoprene epoxydiols (IEPOX) [19,20]. IEPOX secondary organic aerosols (SOA), which in part consists of tetrols and organosulfates, is formed via the acid-catalyzed ring opening of the epoxide followed by nucleophilic addition of water or anions (e.g., $\mathrm{HSO}_{4}{ }^{-}$). In laboratory studies, IEPOX SOA has been found to form most efficiently at low $\mathrm{pH}$ as a result of the acid-catalyzed ring-opening step. The low $\mathrm{pH}$ and high nucleophile concentrations in aqueous aerosol provide a favorable environment for IEPOX SOA formation [21]. However, a number of scenarios which are believed to be common for aqueous aerosols, such as organic coatings, phase separation, or low-viscosity aerosols [22-31], are known to result in mass transfer limitations which inhibit the uptake of IEPOX into aqueous aerosols, limiting subsequent IEPOX SOA formation. Despite this, IEPOX SOA is observed ubiquitously in the environment [19,20,29,32]. Therefore, it is possible that cloudwater may be a greater source of IEPOX SOA than previously believed [8]. Although the lower acidity and sulfate concentrations of cloudwater would make the rate of IEPOX SOA formation in cloudwater lower than in aqueous aerosol, other factors, such as high liquid water content and lack of organic coating or viscosity-based mass transfer limitations, may promote SOA formation [33,34].

Currently, some regional and global models cannot accurately predict atmospheric aqueous organic material due to uncertainties in SOA production despite the availability of detailed chemical models representative of atmospheric processes [3,7,35]. Such discrepancies between models and observed measurements may be attributed, in part, to the lack of consideration of the cycling between cloudwater and aqueous aerosol in the models. Although several models have shown that SOA formation does occur in cloudwater, the extent to which SOA is produced as compared to formation in aqueous aerosol is unclear since very few models represent both processes [8,36-39]. In this work, we aim to compare IEPOX SOA production in both cloudwater and aqueous aerosols while considering the cycling that can occur between the two phases upon evaporation or condensation of water. We used a recently updated version of GAMMA (Gas-Aerosol Model for Mechanism Analysis), a photochemical box model developed by the McNeill group, to quantify IEPOX SOA formation. We previously used GAMMA and a related model, simpleGAMMA, to predict IEPOX SOA in aqueous aerosols, and the results were in good agreement with ambient measurements [21,40-43]. The recent update to GAMMA includes uptake of IEPOX and subsequent formation of SOA in cloudwater, allowing for the direct comparison of the efficiency of IEPOX SOA formation in both aqueous environments, and captures the coupled effect of the two modes of processing in a single simulation.

\section{Methods}

In this study, all simulations are based on conditions taken from ambient measurements at Whiteface Mountain and performed in GAMMA, as described in the following sections [13].

\subsection{GAMMA 5.0}

GAMMA is a photochemical box model developed by the McNeill group, which includes gas phase and aqueous phase species of organic material. The reactions and tracked species in GAMMA are summarized and discussed by McNeill et al. (2012) [21]. The evolution of each species is represented by: 


$$
\begin{gathered}
\frac{d P_{i}}{d t}=-k_{m t, i} a_{L} P_{i}+\frac{k_{m t, i} a_{L}}{H_{i}^{*}} C_{i}+\sum_{j} r_{i j, g a s}+E_{i}-D_{i}, \\
\frac{d C_{i}}{d t}=\frac{k_{m t, i}}{\mathbf{R} T} P_{i}-\frac{k_{m t, i}}{H_{i}^{*} \mathbf{R} T} C_{i}+\sum_{j} r_{i j, a q,}
\end{gathered}
$$

where $P_{i}$ is the concentration of species $i$ in the gas phase, $C_{i}$ is the concentration of species $i$ in the aqueous phase, $k_{m t, i}$ is the gas-aqueous phase mass transfer coefficient, $a_{L}$ is the aqueous aerosol liquid volume fraction, $H_{i}{ }^{*}$ is the effective Henry's Law constant, $E_{i}$ is the emission rate, $D_{i}$ is the deposition rate, $\mathrm{R}$ is the gas constant, $T$ is temperature, and $r_{i j, g a s}$ and $r_{i j, a q}$ are the gas and aqueous phase reactions of species $i$, respectively [44]. A list of reactions represented by $r_{i j, g a s}$ and $r_{i j, a q}$ can be found in the Supporting Information provided by McNeill et al. [21] and Woo et al. [45]. As seen in Equations (1) and (2), the gas and aqueous phases of a species $i$ are coupled in GAMMA by the mass transfer terms. In GAMMA 5.0, these equations represent the temporal evolution of aqueous species in both aerosol and cloudwater and mass transfer of gas phase species to and from aerosol and cloudwater. More detailed information regarding GAMMA, including Henry's constants used and equations calculating uptake of gas-phase species, can be found in previous work using older versions of GAMMA [21,46].

For transitions between cloudwater and aqueous aerosols, a unitless scaling factor, $f_{w}$, is calculated as the ratio of the liquid water fraction in cloudwater to the liquid water fraction in aqueous aerosol, in order to adjust aqueous phase concentrations based on the differences in the amount of liquid water available. This factor is assumed to be $5.9 \times 10^{4}$ for this study, determined from ambient measurements for cloudwater [13] and from E-AIM model II, a thermodynamic model which can calculate equilibrium concentrations of aqueous phase species in aerosols, for aerosol [47,48]. The liquid water fraction is assumed to be constant except at these transitions. When transitioning from aqueous aerosol to cloudwater, all condensed phase species concentrations are scaled by a factor of $f_{w}{ }^{-1}$, except for water, which is set to $55.5 \mathrm{~mol} \mathrm{~L}^{-1}$. When transitioning from cloudwater to aqueous aerosol, concentrations of condensed phase species, except water, are instead scaled by a factor of $f_{w}$. The water concentration and relative humidity are set back to the initial conditions determined from E-AIM. The aerosol particle radius is set back to the initial radius, specified as $48 \mathrm{~nm}$ for this work, as all simulations in this study start with aqueous aerosols before cycling. Both transitions are treated as instantaneous by GAMMA, and chemistry of evaporation, other than that due to dilution and concentration, is not considered $[49,50]$. Conditions that differ for aqueous aerosol and cloudwater are summarized in Table 1. All conditions shown in this table are specified for this work and can be changed based on the aqueous system of interest, except for the water concentration and relative humidity for cloudwater.

Table 1. Difference in conditions for aqueous aerosol mode and cloudwater mode for this study in GAMMA 5.0.

\begin{tabular}{ccc}
\hline & Aqueous Aerosol & Cloudwater \\
\hline Liquid water fraction & $1.36 \times 10^{-11} \mathrm{~cm}^{3} \mathrm{~cm}^{-3}$ & $8.0 \times 10^{-7} \mathrm{~cm}^{3} \mathrm{~cm}^{-3}$ \\
Water concentration & $46.1 \mathrm{~mol} \mathrm{~L}$ & $55.5 \mathrm{~mol} \mathrm{~L}^{-1}$ \\
Relative humidity & $80 \%$ & $100 \%$ \\
Radius of particle or cloud droplet & $48 \mathrm{~nm}$ & $10 \mu \mathrm{m}$ \\
\hline
\end{tabular}

Aqueous processing of IEPOX is represented in GAMMA as a branching reaction with 2-methyltetrols (tetrol) and IEPOX organosulfate (IEPOX OS) as products. Following Eddingsaas et al. [34], the branching ratio of 0.4 at the highest measured acidity is used for IEPOX OS for each GAMMA simulation. Additionally, $36 \%$ of the tetrols is assumed to partition to the gas phase, by taking an average of measured ambient data points from previous studies of volatility of these species [51]. IEPOX OS is assumed to be nonvolatile, and as such serves as a proxy for other potential low-volatility species such as IEPOX OS oligomers [28]. An effective Henry's Law constant of $3 \times 10^{7} \mathrm{~mol} \mathrm{~L}^{-1} \mathrm{~atm}^{-1}$ is used for IEPOX partitioning to the aqueous phase, based on GAMMA simulations of the laboratory data of Nguyen et al. (2014) [33]. The formation of IEPOX SOA is dependent on $\mathrm{pH}$ and sulfate concentration, 
both of which change during the aerosol-cloudwater cycling, as previously described [34,41]. Note that no mass transfer limitations are considered for the aerosol calculations, making our calculations of IEPOX SOA formation during the aerosol portion of the aerosol-cloud cycle an upper bound.

\subsection{Simulation Conditions}

Initial conditions were based on published conditions for Whiteface Mountain, including initial conditions for gas phase concentrations, aqueous phase concentrations, temperature, pressure, and humidity summarized in Tables S1-S3 (see Supplementary Materials) [13]. Initial conditions for aqueous phase inorganic ion concentrations were determined using E-AIM and the assumed initial aerosol $\mathrm{pH}$. Each simulation was $12 \mathrm{~h}$ long, from 6 a.m. to 6 p.m., however, the times at which the aqueous aerosol and the cloudwater phases were present varied between runs. In the first set of simulations, aqueous aerosols were present in the first six hours and cloudwater was present in the final six hours, with the transition between the two occurring at $12 \mathrm{p} . \mathrm{m}$. In the second set of simulations, aqueous aerosols were present in the first three hours and the last three hours, while cloudwater was present in the middle six hours. Thus, these simulations also considered cycling from cloudwater back to aqueous aerosol. The times at which GAMMA was in cloudwater mode for these two sets of simulations are shown in Figure 1. In each set of simulations, the $\mathrm{pH}$ was varied between subsequent runs from 1 to 4 for aqueous aerosols and 3 to 6 for cloudwater, which included typical ranges for each, but was set constant within each throughout the duration of each aerosol or cloudwater phase $[8,21,38,52,53]$. Photolysis rates for Whiteface Mountain were determined from Troposphere Ultraviolet and Visible (TUV) radiation model version 5.3 and were assumed to be the same throughout the cloud parcel. These rates were updated for each minute of the GAMMA simulations.

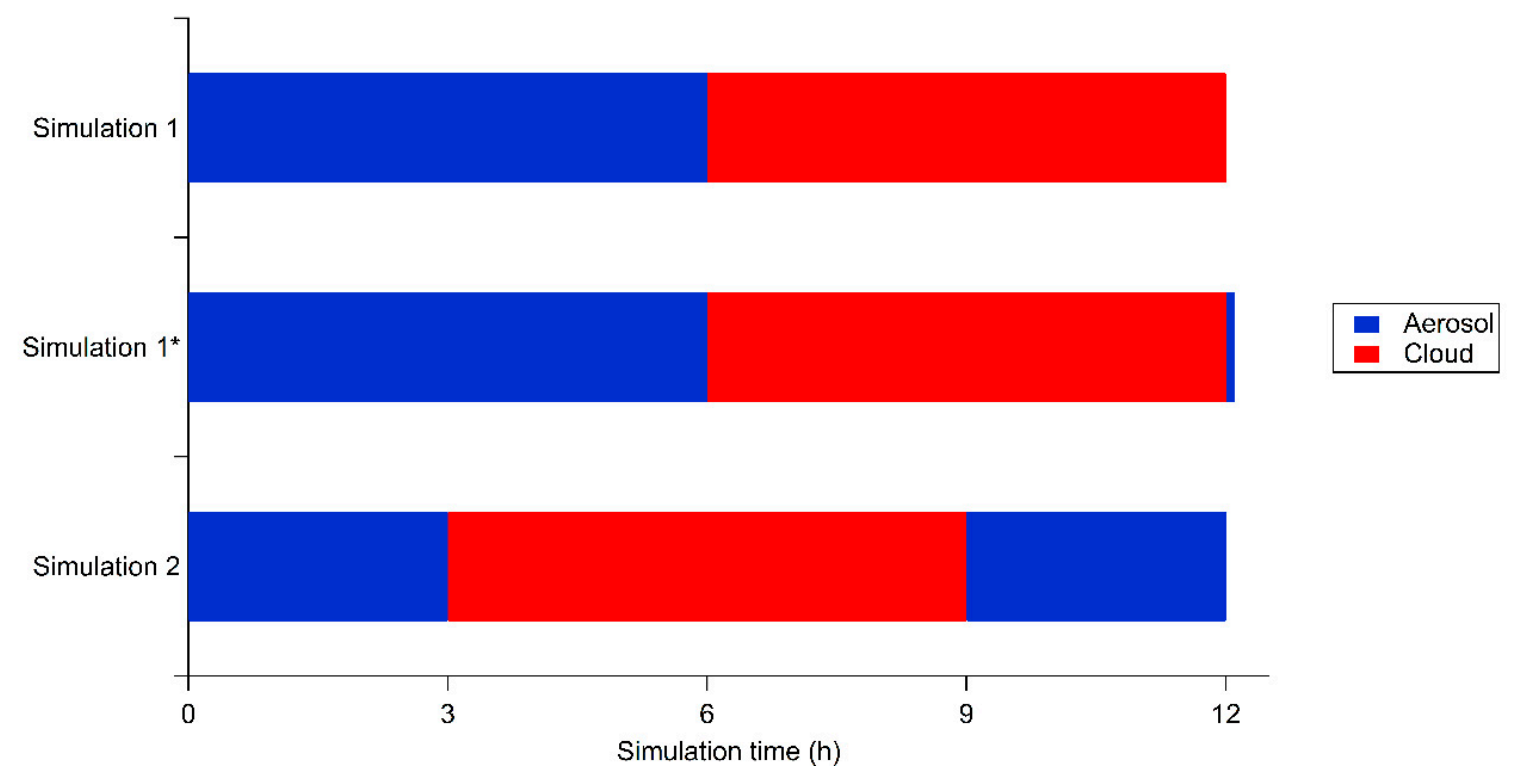

Figure 1. Times at which GAMMA is in each aqueous mode for the three sets of simulations considered in this work.

Simulation 1 ended with the condensed phase as cloudwater, whereas Simulation 2 ended with the condensed phase as aqueous aerosol. The difference in aqueous environments resulted in difficulty in comparing the final concentrations after $12 \mathrm{~h}$ of simulation, due to the revolatilization of some semivolatile organics that occurred upon transition from the cloud to the aerosol. For this reason, another set of simulations, called Simulation $1^{*}$, was performed where an additional minute was added onto the end of Simulation 1. The condensed phase transitioned from cloudwater to aqueous aerosol in that additional minute. The purpose of Simulation $1^{*}$ was to quantify the persistent aqueous SOA created during aerosol and cloud processing in Simulation 1, such that the results of Simulations 1 and 
2 could be more directly compared. GAMMA treats Henry's Law partitioning as spontaneous at every time step (Equations (1) and (2)), so one minute was sufficiently long to repartition semivolatile species to the gas phase without significant additional aqueous aerosol-phase chemical processing.

\section{Results}

Concentrations of aqueous phase species throughout the $12 \mathrm{~h}$ for all simulations are compared for different aerosol and cloud $\mathrm{pH}$. Figure 2 shows the aqueous phase organic acids, carbonyl-containing VOCs (CVOCs), IEPOX (labelled IEPOXaq), and IEPOX SOA (labelled IEPOXpathway) for a Simulation 1 run with aerosol $\mathrm{pH} 1$ and cloud $\mathrm{pH}$ 4. Organic acids include glyoxylic acid, oxalic acid, pyruvic acid, acetic acid, formic acid, glycolic acid, succinic acid, and malonic acid and their ionized forms. The CVOCs include glyoxal, methylglyoxal, glycolaldehyde, and other aldehydes.

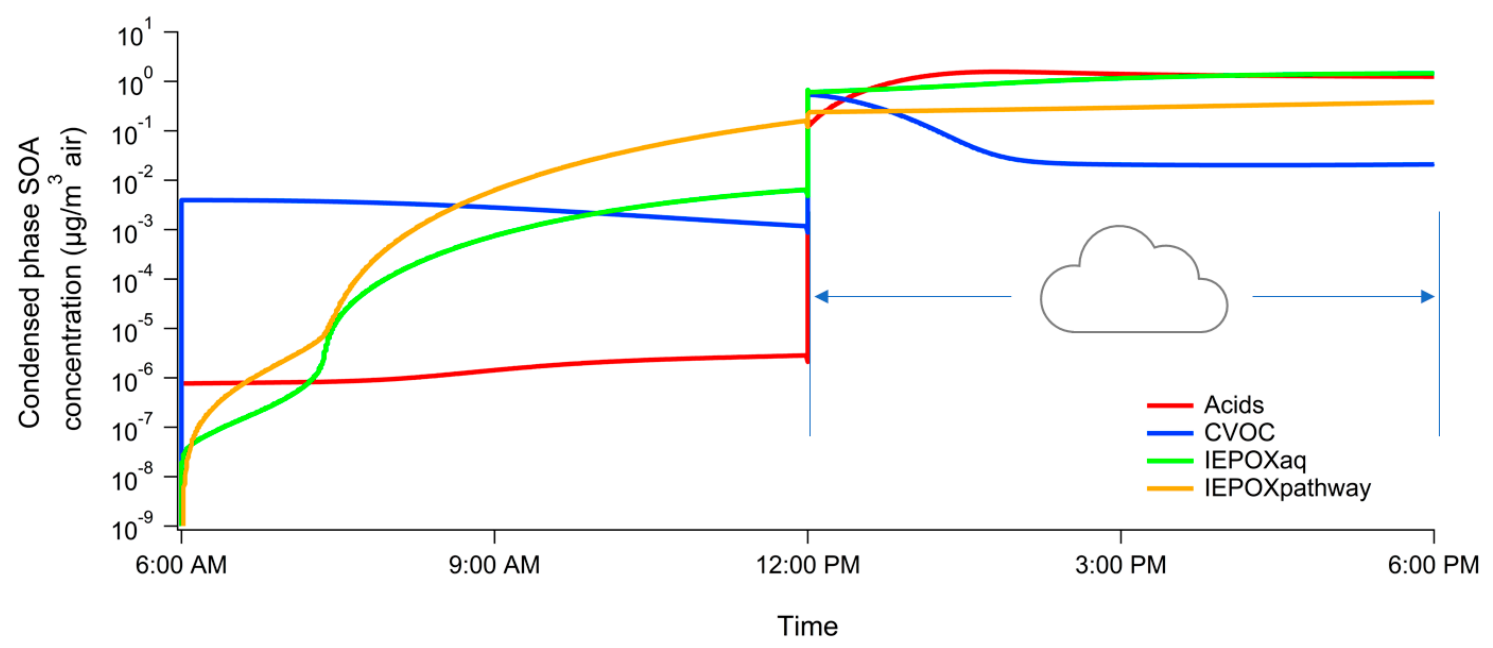

Figure 2. Organic acids, carbonyl-containing VOCs (CVOCs), isoprene epoxydiol (IEPOX), and IEPOX secondary organic aerosols (SOA) mass concentrations in Simulation 1 with aerosol $\mathrm{pH} 1$ and cloud $\mathrm{pH} 4$.

IEPOX and organic acids need to form in the gas phase prior to partitioning to the aerosol phase, resulting in CVOCs dominating at short simulation times due to different initial rates of formation. After six hours of photochemistry in the gas and aqueous aerosol phases, IEPOX SOA largely dominates, consistent with previous studies [21,40], however, there is a sharp increase in the mass of volatile species in the aqueous phase per volume of air following the transition to cloudwater. Because the liquid water fraction for cloudwater is approximately $10^{4}$ times greater than that for aqueous aerosol in this work, aqueous phase concentrations are diluted by this factor, $f_{w}$, as well, creating a large concentration gradient for mass transfer into the condensed phase. This behavior is observed for both Simulations 1 and 2 at every $\mathrm{pH}$ considered. After one hour of cloudwater processing, organic acids are the most abundant species of these four groups, also as expected due to the greater availability of oxidants in cloudwater [8]. However, IEPOX SOA concentrations continue to increase as well, due to ongoing aqueous-phase chemistry and isoprene emissions that persist throughout the day.

On the basis of the known dependence of IEPOX SOA formation on $\mathrm{pH}$, varying cloud $\mathrm{pH}$ in the second half of Simulation 1 is considered and the results are shown in Figure 3. In this figure, only IEPOX SOA and organic acids are compared since they are found to be the most abundant organic species besides IEPOX, as observed in Figure 2. The concentrations of these species are plotted after the first six hours of the simulation (aqueous aerosol processing), and the organic mass is found to be $99 \%$ IEPOX SOA for aerosols of $\mathrm{pH} 1$. After the initial aqueous aerosol processing, the figure shows four separate cases of cloud processing for the next six hours of the simulation, at cloudwater $\mathrm{pH}$ ranging from 3 to 6 . Although there is some IEPOX SOA formation at cloud $\mathrm{pH} 5$ and 6 , due to the acid catalysis requirement of the IEPOX SOA mechanism, it is more limited than the production of 
organic acids via the oxidation of CVOCs. However, for more acidic cloudwater, IEPOX SOA formation increases until it makes up almost $50 \%$ of aqSOA at the completion of the simulation, for cloudwater $\mathrm{pH}$ 3. Furthermore, for cloudwater $\mathrm{pH} 3$, less than 15\% of the total mass of IEPOX SOA was formed during the aerosol phase period of the simulation, suggesting the significance of cloudwater processes for IEPOX SOA formation.

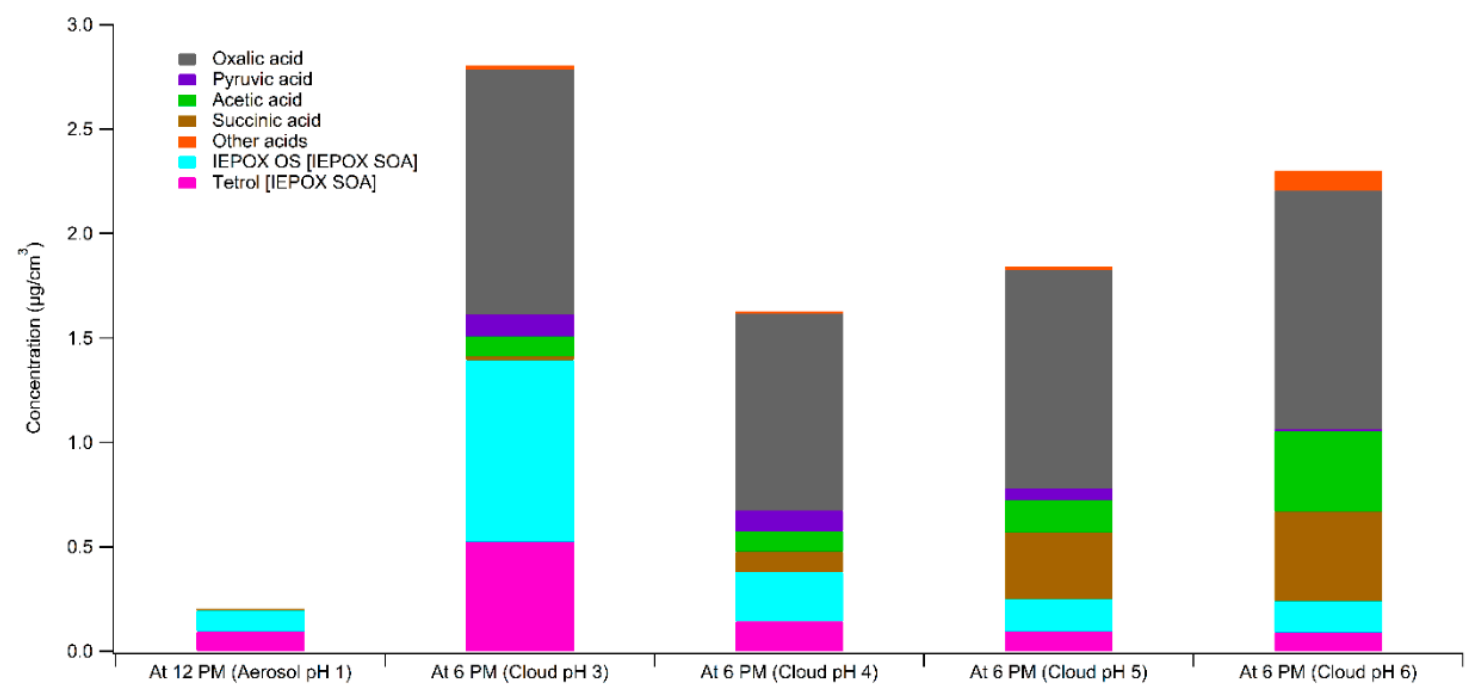

Figure 3. Organic acids and IEPOX SOA in the aqueous phase in Simulation 1 with aerosol pH 1 and cloud $\mathrm{pH} 3$ to 6 . The graphs for cloud $\mathrm{pH} 3$ to 6 indicate composition at the end of the simulation at 6 p.m. Concentrations are given in mass per volume of air parcel.

In comparing IEPOX SOA formation at various $\mathrm{pH}$ for Simulation 1 , the average formation rates at each $\mathrm{pH}$ for both aqueous aerosol and cloudwater were calculated. These results are plotted in Figure 4. As expected, due to the role of acid catalysis in aqueous-phase processing of IEPOX, increasing the $\mathrm{pH}$ in all cases for both cloudwater and aqueous aerosol while keeping the other constant results in a slower rate of IEPOX SOA formation [19]. Additionally, for cloud $\mathrm{pH} 5$ and 6, the formation rates in cloudwater for every case are less than that of aerosol $\mathrm{pH} 1$, consistent with a previous analysis [8]. However, this trend changes when cloud $\mathrm{pH}$ is reduced to 4 , where formation of IEPOX SOA in cloudwater at all $\mathrm{pH}$ is comparable to formation in aerosol $\mathrm{pH}$ 1. At cloud $\mathrm{pH} 3$, IEPOX SOA formation rates in cloudwater are approximately 10 times greater than in aerosol $\mathrm{pH}$. Thus, due to the relatively large liquid water content of clouds, cloudwater processing can be a significant source of IEPOX SOA at $\mathrm{pH} \leq 4$, whereas stronger acidity is required for efficient IEPOX SOA formation in aqueous aerosols [21,22]. Although large IEPOX SOA production rates are observed for cloudwater, it should be noted that the rates are taken as an average over the entire six hours after cycling from aerosol. This includes the sharp increase due to rapid mass transfer of IEPOX into the aqueous phase seen shortly after the six-hour point of the simulation. Since this sharp increase does not occur again throughout the remainder of the six hours, the average formation rate is skewed high due to the beginning of the six hours. If the cloudwater phase were to run for longer than six hours, the average rate would decrease. On the other hand, aerosol-cloud cycling may occur on shorter timescales [54,55], in which case this initial dilution effect would be more prominent. Even a small amount of time of IEPOX processed in cloudwater can lead to considerable SOA growth. 


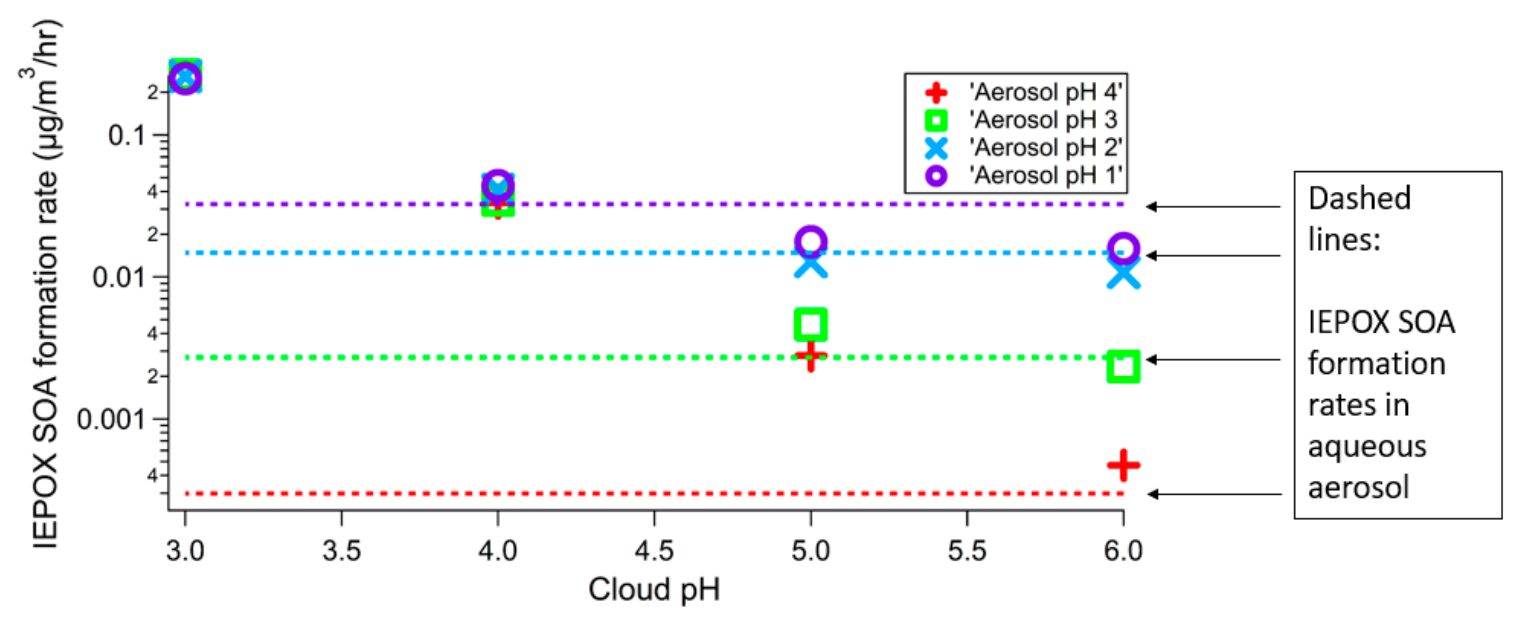

Figure 4. Comparison of IEPOX SOA formation rates in Simulation 1 for aerosol pH 1 to 4 and cloud $\mathrm{pH} 3$ to 6 . Rates are averaged over the entire six hours of the corresponding phase. Each individual point corresponds to the IEPOX SOA formation rate in cloudwater in the second half of the simulation with the $\mathrm{pH}$ of the aerosol in the first half of the simulation represented by the shape and color of the point as described in the legend. The same colors are used in the horizontal dashed lines corresponding to the formation in aqueous aerosols at the same $\mathrm{pH}$ in the first half of the simulation.

A similar analysis was performed for Simulation 2, where organic acids, CVOCs, IEPOX, and IEPOX SOA concentrations were compared at aerosol-cloud transitions. Figure 5, which tracks these four groups of species, shows a sharp increase in aqueous phase organic material shortly after transitioning to cloudwater, similar to Simulation 1. When cycling back to aqueous aerosol, a drop in aqueous phase organic material is observed due to the decrease in water content in the aerosol, creating a concentration gradient driving partitioning back to the gas phase. This drop is not observed for all species due to varying volatilities of aqueous-phase organics. This is more clearly seen in Figure 6, which shows the fraction of organic acids and IEPOX SOA for the following two cases of Simulation 2: (1) aqueous aerosol processing at $\mathrm{pH} 1$, cloudwater at $\mathrm{pH} 4$, and aqueous aerosol again at $\mathrm{pH} 1$; and (2) aqueous aerosol processing at $\mathrm{pH} 1$, cloudwater at $\mathrm{pH} 5$, and aqueous aerosol again at $\mathrm{pH} 1$. The primary difference in composition between the initial and final composition of the aqueous aerosol after cloudwater processing is the lack of more volatile acids, such as pyruvic acid, in the final composition. The species that remain in the aqueous phase have higher Henry's Law constants [21].

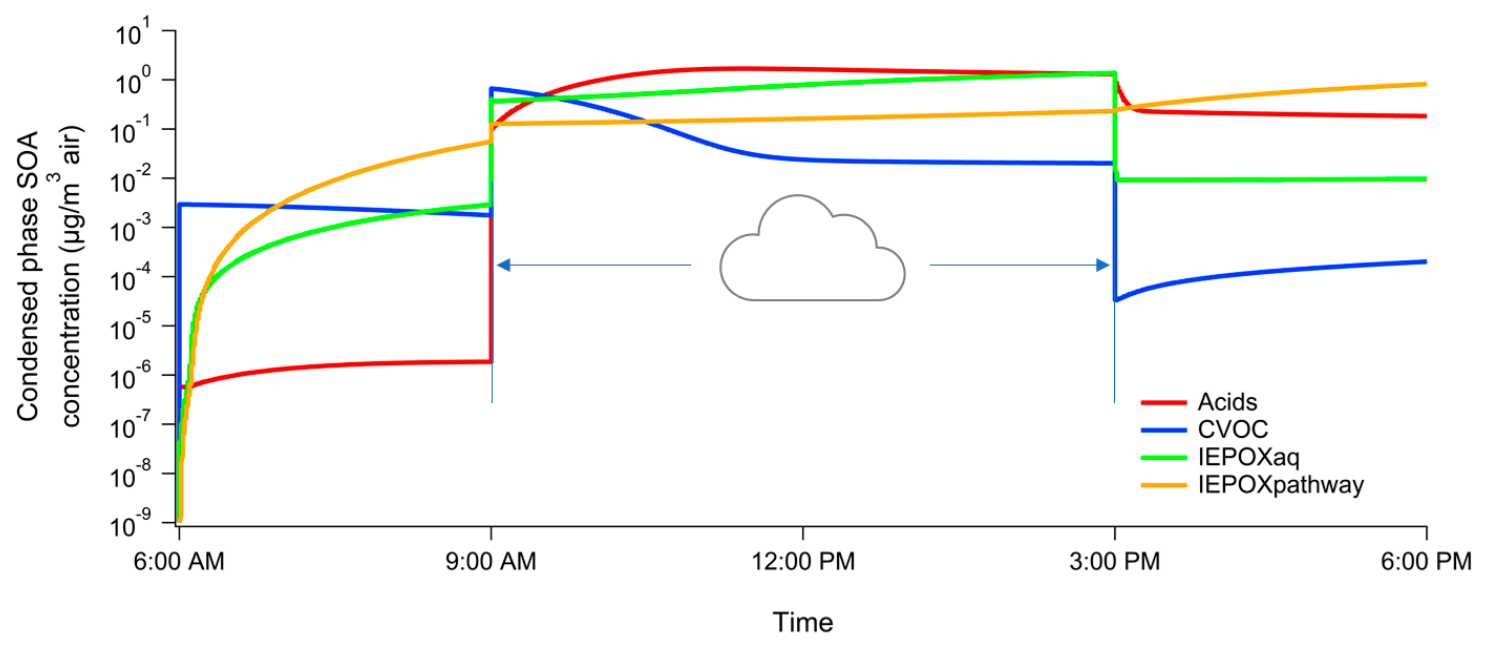

Figure 5. Organic acids, CVOCs, IEPOX, and IEPOX SOA mass concentrations in Simulation 2 with aerosol pH 1 and cloud $\mathrm{pH} 4$. 


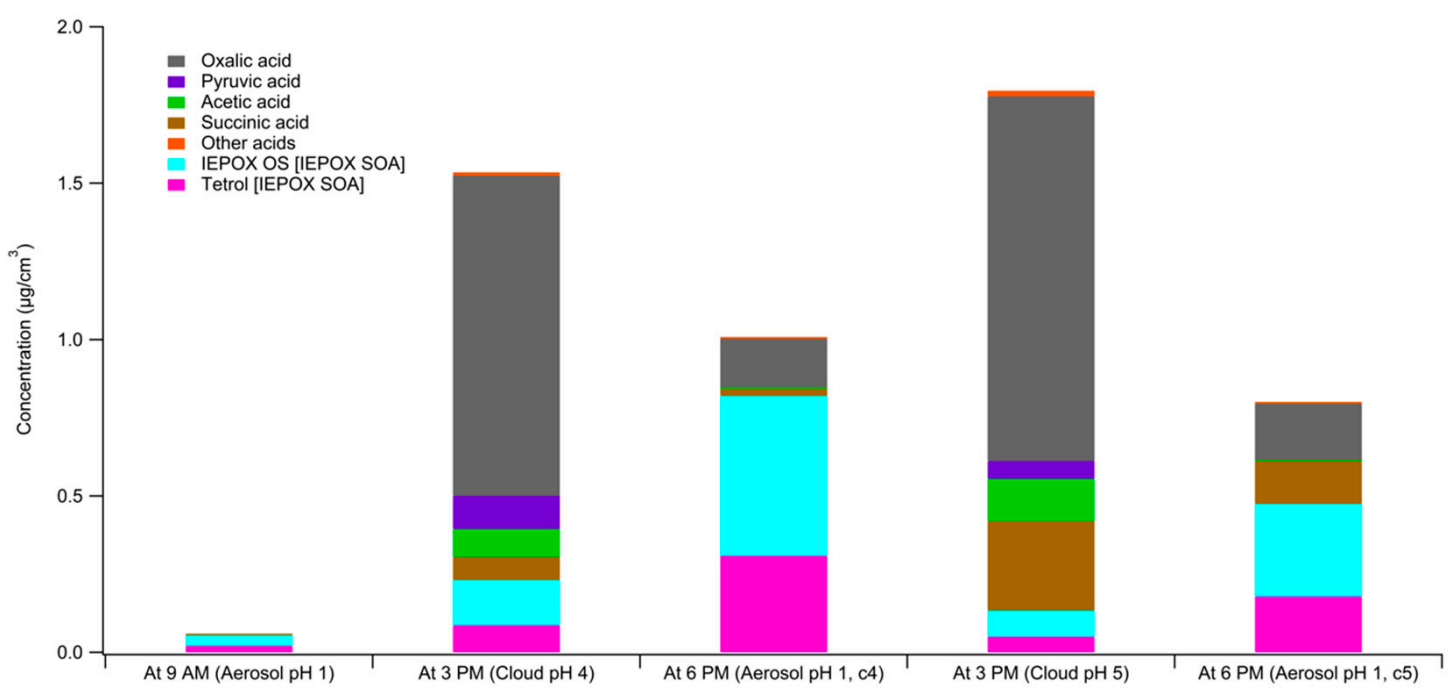

Figure 6. Organic acids and IEPOX SOA in the aqueous phase for Simulation 2 with aerosol pH 1 and cloud $\mathrm{pH} 4$ or 5 . The two bars labeled $\mathrm{c} 4$ and c5 at 6 PM correspond to Simulation 2 with cloud pH 4 and 5, respectively, as the starting and ending aerosol $\mathrm{pH}$ are the same while the intermediate cloud $\mathrm{pH}$ differs. Concentrations are given in mass per volume of air parcel.

For Simulation 2, cloud $\mathrm{pH}$ is observed to be the most important variable for IEPOX SOA formation. After three hours of aqueous aerosol processing, IEPOX SOA is more abundant than organic acids, as seen in Figure 6. However, the total aqSOA mass is $5.50 \times 10^{-2} \mu \mathrm{g} \mathrm{m}^{-3}$, which is insignificant relative to a mass of $1.54 \mu \mathrm{g} \mathrm{m}^{-3}$ and $1.80 \mu \mathrm{g} \mathrm{m}^{-3}$ after cloudwater processing for cloud $\mathrm{pH} 4$ and 5 , respectively. This is due to the comparatively low liquid water content of the aerosol phase. In this example, $\mathrm{pH} 4$ or 5 for cloudwater is sufficient for IEPOX SOA formation, although organic acid formation is still more dominant.

The final mass fractions of IEPOX SOA and organic acids for Simulations $1,1 *$, and 2 are shown in Figure 7. As previously noted, the end of Simulation 1 has most of the acids produced in cloudwater still in the aqueous phase, largely due to the relatively high-water content in cloudwater, however, extending the simulation by one minute to cycle back to aqueous aerosol is sufficient for most of the volatile organic acids to partition to the gas phase, leaving primarily oxalic acid, succinic acid, and IEPOX SOA in the aqueous phase. Comparing the final mass fractions in Simulations $1^{*}$ and 2, IEPOX SOA formation is greater in Simulation 2. The masses of lower-volatility organic acids are similar, but greater for Simulations 1 and $1^{*}$. Since each simulation includes the same total duration of aerosol phase and cloud phase chemistry, the difference shown in Figure 7 may be attributed to the sequence of aerosol-cloud cycling. Although isoprene emissions are assumed to be constant throughout the duration of this daytime-only simulation, the different times specified for aqueous aerosol and cloudwater results in the extent of partitioning to differ throughout the day. As more isoprene has been emitted cumulatively towards later times in the day, this may result in a greater accumulation of isoprene oxidation products when the liquid water fraction of the aqueous phase is lower later in the day, ultimately resulting in variations in IEPOX SOA formation. Another factor attributing to the difference in Simulations $1^{*}$ and 2 is the variation of photolysis rates throughout the day. Photolysis rates are highest at solar noon. This is optimal for organic acid formation and gas-phase IEPOX formation since the availability of oxidants drives both processes. As seen in Figures 3, 6 and 7, cloud $\mathrm{pH}$ and the time of day and sequence all have a significant effect on aqueous $\mathrm{SOA}$ production and composition. 


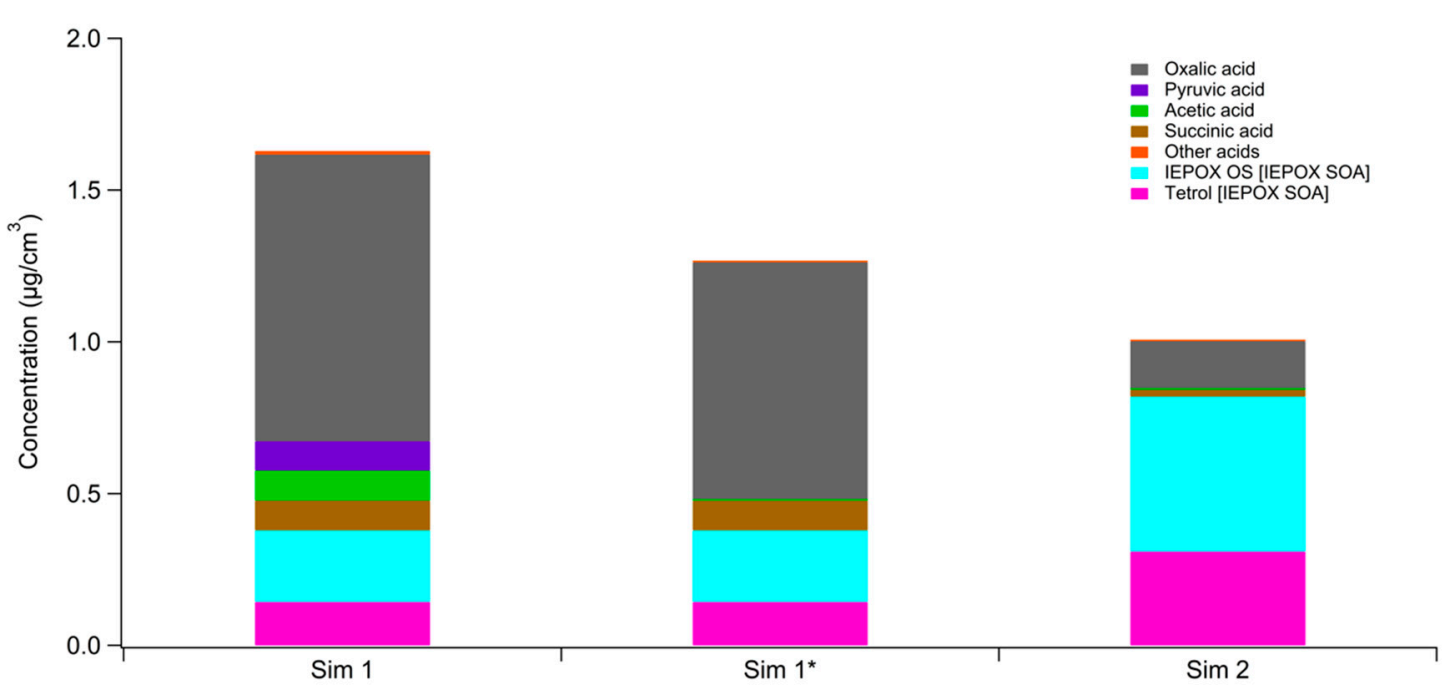

Figure 7. Mass of aqueous phase organic acids and IEPOX SOA at the end of Simulations $1,1^{*}$, and 2 for aerosol $\mathrm{pH} 1$ and cloud $\mathrm{pH}$ 4. Concentrations are given in terms of volume of air.

\section{Atmospheric Implications}

The results of this work indicate that aqueous-phase chemistry in clouds may be a more significant source of IEPOX SOA than previously believed. Production in cloudwater could account for the discrepancy between the expected efficiency of uptake of IEPOX to aqueous aerosols, given mass transfer considerations, and the ubiquity of ambient IEPOX SOA. Since no aerosol-phase mass transfer limitations were considered in our simulations, our calculations of IEPOX SOA formation in aerosol water can be considered to be an upper bound.

Due to a lack of observations of IEPOX SOA tracers in cloudwater and the high variability of liquid water content and $\mathrm{pH}$ in both the aerosol and cloud phases, the percentage of IEPOX SOA produced in cloudwater and aqueous aerosol remains unclear $[11,38,56]$. The observed lack of correlation between SOA mass and several aerosol properties, including liquid water content and $\mathrm{pH}$, for ambient data may also be clarified by considering production in clouds [57]. Due to its potentially large contribution to total SOA mass, cloudwater and its efficiency in producing IEPOX SOA and other SOA should be considered when quantifying sources of organic aerosol.

Supplementary Materials: The following are available online at http://www.mdpi.com/2073-4433/10/11/666/s1, Table S1: Cloudwater simulation conditions, Table S2: Gas phase initial number concentrations specified in GAMMA, Table S3: Initial concentrations of ammonium (bi)sulfate in GAMMA, following E-AIM.

Author Contributions: V.F.M., J.L.W. and W.G.T. contributed to the GAMMA code; W.G.T. conducted the simulations discussed in this study; W.G.T. was the main author of the manuscript; V.F.M. and J.L.W. contributed in the writing process; and V.F.M. acquired the funding for this work and supervised the research.

Funding: This research was funded by the NSF-USA, grant number AGS-1546136.

Conflicts of Interest: The authors declare no conflict of interest.

\section{References}

1. Kanakidou, M.; Seinfeld, J.H.; Pandis, S.N.; Barnes, I.; Dentener, F.J.; Facchini, M.C.; Van Dingenen, R.; Ervens, B.; Nenes, A.; Nielsen, C.J.; et al. Organic aerosol and global climate modelling: A review. Atmos. Chem. Phys. 2005, 5, 1053-1123. [CrossRef]

2. Nguyen, T.K.V.; Zhang, Q.; Jimenez, J.L.; Pike, M.; Carlton, A.G. Liquid Water: Ubiquitous Contributor to Aerosol Mass. Environ. Sci. Technol. Lett. 2016, 3, 257-263. [CrossRef]

3. Jimenez, J.L.; Canagaratna, M.R.; Donahue, N.M.; Prévôt, A.S.H.; Zhang, Q.; Kroll, J.H.; DeCarlo, P.F.; Allan, J.D.; Coe, H.; Ng, N.L.; et al. Evolution of Organic Aerosols in the Atmosphere. Science 2009, 326, 1525-1529. [CrossRef] [PubMed] 
4. de Gouw, J.A.; Jimenez, J.L. Organic Aerosols in the Earth's Atmosphere. Environ. Sci. Technol. 2009, 43, 7614-7618. [CrossRef] [PubMed]

5. Chuang, P.Y. Measurement of the timescale of hygroscopic growth for atmospheric aerosols. J. Geophys. Res. Atmos. 2003, 108, 4282. [CrossRef]

6. Jacob, D.J. Introduction to Atmospheric Chemistry; Princeton University Press: Princeton, NJ, USA, 1999; ISBN 9781680159073.

7. Hallquist, M.; Wenger, J.C.; Baltensperger, U.; Rudich, Y.; Simpson, D.; Claeys, M.; Dommen, J.; Donahue, N.M.; George, C.; Goldstein, A.H.; et al. The formation, properties and impact of secondary organic aerosol: Current and emerging issues. Atmos. Chem. Phys. 2009, 9, 5155-5236. [CrossRef]

8. McNeill, V.F. Aqueous Organic Chemistry in the Atmosphere: Sources and Chemical Processing of Organic Aerosols. Environ. Sci. Technol. 2015, 49, 1237-1244. [CrossRef]

9. Zhang, Q.; Jimenez, J.L.; Canagaratna, M.R.; Allan, J.D.; Coe, H.; Ulbrich, I.M.; Alfarra, M.R.; Takami, A.; Middlebrook, A.M.; Sun, Y.L.; et al. Ubiquity and dominance of oxygenated species in organic aerosols in anthropogenically-influenced Northern Hemisphere midlatitudes. Geophys. Res. Lett. 2007, 34, L13801. [CrossRef]

10. Herckes, P.; Valsaraj, K.T.; Collett, J.L. A review of observations of organic matter in fogs and clouds: Origin, processing and fate. Atmos. Res. 2013, 132-133, 434-449. [CrossRef]

11. Ervens, B.; Sorooshian, A.; Aldhaif, A.M.; Shingler, T.; Crosbie, E.; Ziemba, L.; Campuzano-Jost, P.; Jimenez, J.L.; Wisthaler, A. Is there an aerosol signature of chemical cloud processing? Atmos. Chem. Phys. 2018, 18, 16099-16119. [CrossRef]

12. Seinfeld, J.H.; Pandis, S.N. Atmospheric Chemistry and Physics; European Geophysical Society: Munich, Germany, 1998; Volume 6.

13. Lance, S.; Barth, M.; Carlton, A.; Lance, S.; Barth, M.; Carlton, A. Multiphase Chemistry: Experimental Design for Coordinated Measurement and Modeling Studies of Cloud Processing at a Mountaintop. Bull. Am. Meteorol. Soc. 2017, 98, ES163-ES167. [CrossRef]

14. Adirondack Lakes Survey Corporation-Whiteface Mountain Cloud Monitoring. Available online: http: //www.adirondacklakessurvey.org/wfc.shtml (accessed on 25 September 2019).

15. Pye, H.O.T.; Nenes, A.; Alexander, B.; Ault, A.P.; Barth, M.; Clegg, S.; Collett, J.L., Jr.; Fahey, K.M.; Hennigan, C.J.; Herrmann, H.; et al. The Acidity of Atmospheric Particles and Clouds. Atmos. Chem. Phys. Discuss. 2019. in review.

16. Henze, D.K.; Seinfeld, J.H. Global secondary organic aerosol from isoprene oxidation. Geophys. Res. Lett. 2006, 33, L09812. [CrossRef]

17. Guenther, A.; Karl, T.; Harley, P.; Wiedinmyer, C.; Palmer, P.I.; Geron, C. Estimates of global terrestrial isoprene emissions using MEGAN (Model of Emissions of Gases and Aerosols from Nature). Atmos. Chem. Phys. 2006, 6, 3181-3210. [CrossRef]

18. Carlton, A.G.; Wiedinmyer, C.; Kroll, J.H. A Review of Secondary Organic Aerosol (SOA) Formation from Isoprene. Atmos. Chem. Phys. 2009, 9, 4987-5005. [CrossRef]

19. Surratt, J.D.; Lewandowski, M.; Offenberg, J.H.; Jaoui, M.; Kleindienst, T.E.; Edney, E.O.; Seinfeld, J.H. Effect of acidity on secondary organic aerosol formation from isoprene. Environ. Sci. Technol. 2007, 41, 5363-5369. [CrossRef]

20. Surratt, J.D.; Chan, A.W.H.; Eddingsaas, N.C.; Chan, M.; Loza, C.L.; Kwan, A.J.; Hersey, S.P.; Flagan, R.C.; Wennberg, P.O.; Seinfeld, J.H. Reactive intermediates revealed in secondary organic aerosol formation from isoprene. Proc. Natl. Acad. Sci. USA 2010, 107, 6640. [CrossRef]

21. McNeill, V.F.; Woo, J.L.; Kim, D.D.; Schwier, A.N.; Wannell, N.J.; Sumner, A.J.; Barakat, J.M. Aqueous-Phase Secondary Organic Aerosol and Organosulfate Formation in Atmospheric Aerosols: A Modeling Study. Environ. Sci. Technol. 2012, 46, 8075-8081. [CrossRef]

22. Gaston, C.J.; Riedel, T.P.; Zhang, Z.; Gold, A.; Surratt, J.D.; Thornton, J.A. Reactive Uptake of an IsopreneDerived Epoxydiol to Submicron Aerosol Particles. Environ. Sci. Technol. 2014, 48, 11178-11186. [CrossRef]

23. Pye, H.O.T.; Murphy, B.N.; Xu, L.; Ng, N.L.; Carlton, A.G.; Guo, H.; Weber, R.J.; Vasilakos, P.; Appel, K.W.; Budisulistiorini, S.H.; et al. On the implications of aerosol liquid water and phase separation for organic aerosol mass. Atmos. Chem. Phys. 2017, 17, 343-369. [CrossRef] 
24. Schmedding, R.; Ma, M.; Zhang, Y.; Farrell, S.; Pye,H.O.T.; Chen, Y.; Wang, C.T.; Rasool, Q.Z.; Budisulistiorini, S.H.; Ault, A.P.; et al. $\alpha$-Pinene-Derived organic coatings on acidic sulfate aerosol impacts secondary organic aerosol formation from isoprene in a box model. Atmos. Environ. 2019, 213, 456-462. [CrossRef]

25. Shiraiwa, M.; Berkemeier, T.; Schilling-Fahnestock, K.A.; Seinfeld, J.H.; Pöschl, U. Molecular corridors and kinetic regimes in the multiphase chemical evolution of secondary organic aerosol. Atmos. Chem. Phys. 2014, 14, 8323-8341. [CrossRef]

26. Song, M.; Liu, P.F.; Hanna, S.J.; Li, Y.J.; Martin, S.T.; Bertram, A.K. Relative humidity-dependent viscosities of isoprene-derived secondary organic material and atmospheric implications for isoprene-dominant forests. Atmos. Chem. Phys. 2015, 15, 5145-5159. [CrossRef]

27. Reid, J.P.; Bertram, A.K.; Topping, D.O.; Laskin, A.; Martin, S.T.; Petters, M.D.; Pope, F.D.; Rovelli, G. The viscosity of atmospherically relevant organic particles. Nat. Commun. 2018, 9, 956. [CrossRef]

28. D'ambro, E.L.; Schobesberger, S.; Gaston, C.J.; Lopez-Hilfiker, F.D.; Lee, B.H.; Liu, J.; Zelenyuk, A.; Bell, D.; Cappa, C.D.; Helgestad, T.; et al. Chamber-based insights into the factors controlling epoxydiol (IEPOX) secondary organic aerosol (SOA) yield, composition, and volatility. Atmos. Chem. Phys. 2019, 19, 11253-11265.

29. Hu, W.; Palm, B.B.; Day, D.A.; Campuzano-Jost, P.; Krechmer, J.E.; Peng, Z.; de Sá, S.S.; Martin, S.T.; Alexander, M.L.; Baumann, K.; et al. Volatility and lifetime against $\mathrm{OH}$ heterogeneous reaction of ambient isoprene-epoxydiols-derived secondary organic aerosol (IEPOX-SOA). Atmos. Chem. Phys. 2016, 16, 11563-11580. [CrossRef]

30. Zhang, Y.; Chen, Y.; Lambe, A.T.; Olson, N.E.; Lei, Z.; Craig, R.L.; Zhang, Z.; Gold, A.; Onasch, T.B.; Jayne, J.T.; et al. Effect of the Aerosol-Phase State on Secondary Organic Aerosol Formation from the Reactive Uptake of Isoprene-Derived Epoxydiols (IEPOX). Environ. Sci. Technol. Lett. 2018, 5, 167-174. [CrossRef]

31. Riva, M.; Chen, Y.; Zhang, Y.; Lei, Z.; Olson, N.E.; Boyer, H.C.; Narayan, S.; Yee, L.D.; Green, H.S.; Cui, T.; et al. Increasing Isoprene Epoxydiol-to-Inorganic Sulfate Aerosol Ratio Results in Extensive Conversion of Inorganic Sulfate to Organosulfur Forms: Implications for Aerosol Physicochemical Properties. Environ. Sci. Technol. 2019, 53, 8682-8694. [CrossRef]

32. Hu, W.W.; Campuzano-Jost, P.; Palm, B.B.; Day, D.A.; Ortega, A.M.; Hayes, P.L.; Krechmer, J.E.; Chen, Q.; Kuwata, M.; Liu, Y.J.; et al. Characterization of a real-time tracer for isoprene epoxydiols-derived secondary organic aerosol (IEPOX-SOA) from aerosol mass spectrometer measurements. Atmos. Chem. Phys. 2015, 15, 11807-11833. [CrossRef]

33. Nguyen, T.B.; Coggon, M.M.; Bates, K.H.; Zhang, X.; Schwantes, R.H.; Schilling, K.A.; Loza, C.L.; Flagan, R.C.; Wennberg, P.O.; Seinfeld, J.H. Organic aerosol formation from the reactive uptake of isoprene epoxydiols (IEPOX) onto non-acidified inorganic seeds. Atmos. Chem. Phys. 2014, 14, 3497-3510. [CrossRef]

34. Eddingsaas, N.C.; VanderVelde, D.G.; Wennberg, P.O. Kinetics and Products of the Acid-Catalyzed Ring-Opening of Atmospherically Relevant Butyl Epoxy Alcohols. J. Phys. Chem. A 2010, 114, 8106-8113. [CrossRef]

35. Heald, C.L.; Jacob, D.J.; Park, R.J.; Russell, L.M.; Huebert, B.J.; Seinfeld, J.H.; Liao, H.; Weber, R.J. A large organic aerosol source in the free troposphere missing from current models. Geophys. Res. Lett. 2005, 32, L18809. [CrossRef]

36. Blando, J.D.; Turpin, B.J. Secondary organic aerosol formation in cloud and fog droplets: A literature evaluation of plausibility. Atmos. Environ. 2000, 34, 1623-1632. [CrossRef]

37. Carlton, A.G.; Turpin, B.J.; Altieri, K.E.; Seitzinger, S.P.; Mathur, R.; Roselle, S.J.; Weber, R.J. CMAQ Model Performance Enhanced When In-Cloud Secondary Organic Aerosol is Included: Comparisons of Organic Carbon Predictions with Measurements. Environ. Sci. Technol. 2008, 42, 8798-8802. [CrossRef]

38. Ervens, B.; Turpin, B.J.; Weber, R.J. Secondary organic aerosol formation in cloud droplets and aqueous particles (aqSOA): A review of laboratory, field and model studies. Atmos. Chem. Phys. 2011, 11, 11069-11102. [CrossRef]

39. Ervens, B. Modeling the Processing of Aerosol and Trace Gases in Clouds and Fogs. Chem. Rev. 2015, 115, 4157-4198. [CrossRef]

40. Woo, J.L.; McNeill, V.F. simpleGAMMA v1.0-A reduced model of secondary organic aerosol formation in the aqueous aerosol phase (aaSOA). Geosci. Model. Dev. 2015, 8, 1821-1829. [CrossRef]

41. Budisulistiorini, S.H.; Nenes, A.; Carlton, A.G.; Surratt, J.D.; McNeill, V.F.; Pye, H.O.T. Simulating Aqueous-Phase Isoprene-Epoxydiol (IEPOX) Secondary Organic Aerosol Production During the 2013 Southern Oxidant and Aerosol Study (SOAS). Environ. Sci. Technol. 2017, 51, 5026-5034. [CrossRef] 
42. Budisulistiorini, S.H.; Li, X.; Bairai, S.T.; Renfro, J.; Liu, Y.; Liu, Y.J.; Mckinney, K.A.; Martin, S.T.; Mcneill, V.F.; Pye, H.O.T.; et al. Examining the effects of anthropogenic emissions on isoprene-derived secondary organic aerosol formation during the 2013 Southern Oxidant and Aerosol Study (SOAS) at the Look Rock, Tennessee ground site. Atmos. Chem. Phys. 2015, 15, 8871-8888. [CrossRef]

43. Shrivastava, M.; Andreae, M.O.; Artaxo, P.; Barbosa, H.M.J.; Berg, L.K.; Brito, J.; Ching, J.; Easter, R.C.; Fan, J.; Fast, J.D.; et al. Urban pollution greatly enhances formation of natural aerosols over the Amazon rainforest. Nat. Commun. 2019, 10,1-12. [CrossRef]

44. Schwartz, S.E. Mass-Transport Considerations Pertinent to Aqueous Phase Reactions of Gases in Liquid-Water Clouds; Jaeschke, W., Ed.; NATO ASI Series; Springer: Berlin/Heidelberg, Germany, 1986; Volume G6, pp. 425-471.

45. Woo, J.L.; Kim, D.D.; Schwier, A.N.; Li, R.; Faye McNeill, V. Aqueous aerosol SOA formation: Impact on aerosol physical properties. Faraday Discuss. 2013, 165, 357-367. [CrossRef]

46. Tsui, W.G.; Rao, Y.; Dai, H.-L.; McNeill, V.F. Modeling Photosensitized Secondary Organic Aerosol Formation in Laboratory and Ambient Aerosols. Environ. Sci. Technol. 2017, 51, 7496-7501. [CrossRef]

47. Clegg, S.L.; Brimblecombe, P.; Wexler, A.S. Thermodynamic Model of the System $\mathrm{H}+-\mathrm{NH}_{4}+-\mathrm{SO}_{42}-\mathrm{NO}_{3}$ $-\mathrm{H}_{2} \mathrm{O}$ at Tropospheric Temperatures. J. Phys. Chem. A 1998, 102, 2137-2154. [CrossRef]

48. Clegg, S.L.; Seinfeld, J.H.; Brimblecombe, P. Thermodynamic modelling of aqueous aerosols containing electrolytes and dissolved organic compounds. J. Aerosol Sci. 2001, 32, 713-738. [CrossRef]

49. Nguyen, T.B.; Lee, P.B.; Updyke, K.M.; Bones, D.L.; Laskin, J.; Laskin, A.; Nizkorodov, S.A. Formation of nitrogen- and sulfur-containing light-absorbing compounds accelerated by evaporation of water from secondary organic aerosols. J. Geophys. Res. Atmos. 2012, 117, D01207. [CrossRef]

50. De Haan, D.O.; Corrigan, A.L.; Tolbert, M.A.; Jimenez, J.L.; Wood, S.E.; Turley, J.J. Secondary organic aerosol formation by self-reactions of methylglyoxal and glyoxal in evaporating droplets. Environ. Sci. Technol. 2009, 43, 8184-8190. [CrossRef]

51. Isaacman-VanWertz, G.; Yee, L.D.; Kreisberg, N.M.; Wernis, R.; Moss, J.A.; Hering, S.V.; de Sá, S.S.; Martin, S.T.; Alexander, M.L.; Palm, B.B.; et al. Ambient Gas-Particle Partitioning of Tracers for Biogenic Oxidation. Environ. Sci. Technol. 2016, 50, 9952-9962. [CrossRef]

52. Anastasio, C.; Faust, B.C.; Rao, C.J. Aromatic carbonyl compounds as aqueous-phase photochemical sources of hydrogen peroxide in acidic sulfate aerosols, fogs, and clouds. 1. Non- phenolic methoxybenzaldehydes and methoxyacetophenones with reductants (phenols). Environ. Sci. Technol. 1997, 31, 218-232. [CrossRef]

53. Weber, R.J.; Guo, H.; Russell, A.G.; Nenes, A. High aerosol acidity despite declining atmospheric sulfate concentrations over the past 15 years. Nat. Geosci. 2016, 9, 282-285. [CrossRef]

54. Xue, H.; Feingold, G.; Xue, H.; Feingold, G. Large-Eddy Simulations of Trade Wind Cumuli: Investigation of Aerosol Indirect Effects. J. Atmos. Sci. 2006, 63, 1605-1622. [CrossRef]

55. Feingold, G.; McComiskey, A.; Rosenfeld, D.; Sorooshian, A. On the relationship between cloud contact time and precipitation susceptibility to aerosol. J. Geophys. Res. Atmos. 2013, 118, 10544. [CrossRef]

56. Sareen, N.; Waxman, E.M.; Turpin, B.J.; Volkamer, R.; Carlton, A.G. Potential of aerosol liquid water to facilitate organic aerosol formation: Assessing knowledge gaps about precursors and partitioning. Environ. Sci. Technol. 2017, 51, 3327-3335. [CrossRef]

57. Xu, L.; Guo, H.; Boyd, C.M.; Klein, M.; Bougiatioti, A.; Cerully, K.M.; Hite, J.R.; Isaacman-VanWertz, G.; Kreisberg, N.M.; Knote, C.; et al. Effects of anthropogenic emissions on aerosol formation from isoprene and monoterpenes in the southeastern United States. Proc. Natl. Acad. Sci. USA 2015, 112, 37-42. [CrossRef]

(C) 2019 by the authors. Licensee MDPI, Basel, Switzerland. This article is an open access article distributed under the terms and conditions of the Creative Commons Attribution (CC BY) license (http://creativecommons.org/licenses/by/4.0/). 